\title{
ROMANIA IN THE CONTEXT OF SUSTAINABLE AND FUNCTIONAL GLOBALIZATION. MACROECONOMIC POLICIES AND STRATEGIES FOR MANAGING THE REGIONAL AND GLOBAL INTEGRATION OF THE ROMANIAN COMPETITIVE SPACE
}

\author{
Marius Calin Benea ${ }^{1}$
}

DOI: https://doi.org/10.31410/ERAZ.2019.119

\begin{abstract}
The emerging assemblage of the absorption markets, managed by the very nature of the competitive mechanisms, manifests in the contemporary period ample diversifications under the incidences exerted by the direction of foreign capital flows. The case of Romania is by far a particular one, delimited by the emergence of the consumption behavior of the population, which enables the effects of dislocation of the forms under which the operating procedures of the multinational corporations are usually portrayed. Certainly, the economic and institutional reforms undertaken and carried out by Romania in the long term, even since 1990, have been and continue to represent the central pivot in boosting competitive advantages and, last but not least, in favoring an ascending trend of social welfare as an expression of the degree of economic development and meeting the requirements of integrated competition spaces. Undoubtedly, the economic and institutional reforms undertaken and carried out by Romania in the long term since 1990 have been and continue to be the key pillar in boosting competitive advantages and, last but not least, in favoring an ascending trend of social welfare, that expression of the degree of economic development and satisfaction of the requirements of the integrated competition spaces. In this regard, multinational corporations can exert direct and indirect effects on the evolutions in the spectrum of investment development from implantation economies, the latter being able to be argued in the form of actual investment activities or those carried out under the system of inter-state corporate cooperation, by absorbing the potential of local firms.
\end{abstract}

Keywords: Romania, globalization, macroeconomic, integration, competition.

\section{INTRODUCTION}

$T^{1}$ he process of Romania's economic development has essentially, over time, multiple manifestations, but being the result of the investments made by multinational operators in the economy is not one of them. Romania's competitive advantages are diversified: from the demographic potential to the specific infrastructure and associated technological processes or attuned to the case associated to those. Rendering them fruitful in time has led to an ever-increasing consolidation of an organic integration perspective and structural fluidization of the multinational corporations' mechanisms within the Romanian management systems. More than that, the contribution of multinational corporations to Romania's economic development has, in the current period, substantial developments, materialized in particular in the connection of the technical and technological structures to the industrial standards imposed by the ample process of globalization of the contemporary world economy. 


\section{CONTRIBUTION OF INVESTMENTS MULTINATIONAL CORPORATIONS TO THE ECONOMIC DEVELOPMENT OF ROMANIA}

In the world spectrum, the distinction between outsourced forms of capital source establishment, specific to multinational operators (bank loans, bonds or even portfolios of titles assimilated in the construction of investment capital) whose purpose is to build local investment capacities and direct investment of multinational corporations, consists in the fact that they only favor the structural internalization of external corporate economies in the presence of sufficiently competitive subsidiaries in terms of the efficiency of local, regional or even global production processes. In this regard, multinational corporations can exert direct and indirect effects on developments in the investment development spectrum of implantation economies, which can be argued in the form of actual investment activities or those carried out under the system of inter-state corporate cooperation, by absorbing the potential of local businesses.

A particular analytical problem is represented by the impact of multinational corporations' investments on the Romanian economy, these being approached from the perspective of the driving effects on the local market and the investment activity as a whole.

In this orientation, the ideal approach of the direct impact of the multinational corporations on the implantation states and implicitly on the Romanian economy presupposes the comparative analysis of the corporate investments and those specific to the domestic companies, in the sense of the contributions made to the level of the economic and social development. However, the vast majority of countries do not develop separate studies in the field of concrete analysis of how capital expenditure is earmarked and allocated to economic systems. From this point of view, inflows of foreign direct investment constitute a reference element in the study of multinational corporation interdependencies - implant savings, despite the evaluation imperfections resulting from the application of specific procedures. (The reason for the advanced approach is that direct capital investment is a form of financing the expenses incurred by subsidiaries of multinational corporations and, at the same time, an estimated mode used to predict external balance of payments developments, and direct productive investments are nothing more than the expression of the public budget).

Therefore, the analysis of the direct impact of the multinational corporations on the Romanian economy involves assimilation of the results of the dual and comparative evaluation of the inflows of foreign investments, together with their contribution to the formation of the industrial capital of the implant branch. Essentially, the importance of addressing the direct impact of foreign capital investment on implant savings, and, on Romania, has multiple valences and at the same time, meaningful meanings on the structuring of industrial and competitive relations in the national economic system, the upward trend of Romania's regional and global integration, being more than obvious.

\section{ROMANIAN MULTINATIONAL PERSPECTIVE: "HOLDINGS" AND "COMPANIES"}

The Romanian competition space is currently based on the construction of an investment regime permissible for multinational operators, materialized in several structural coordinates sufficiently flexible and fully connected to the exigencies of Romania's regional and global integration process, which can be delimited as follows: 
a) the possibility of supporting a holding structure or a group of companies;

b) the fluid development of foreign trade relations with a sufficiently competitive transnationalization compared to other investment regions in Central and Eastern Europe, especially under the tariff and the non-tariff regime applied in accordance with the provisions of the Common Market and implicitly of the European Union as a reference in the structuring of its legislative and organizational framework to a full functionality of the internal and external competition mechanism, the latter having as a premise the regulations of the integrated economic spaces which Romania is a partner;

c) the opportunity to deploy the strategic categories on a global scale by major foreign capital investment operators in the areas of utmost importance to assimilate sustainable economic growth and, at the same time, to ensure compatibility with the structural requirements of specialized industries in developed countries;

d) streamlining credit and lending systems and policies practiced on a regional and, in particular, European scale by assimilating specific functional mechanisms Multinational Consortia with conglomerate character.

Thus, the aggregation of investment structures in the form of globally managed operational centers [1] has seen in the contemporary period a diversified amplitude manifested in the Holding Companies [2]. As a whole, this management approach is applicable to the competitive and institutional framework in Romania, despite the absence of a legislative system regulating the specificity of this form of investment management. However, the differences between the standardized system of companies, based on the Companies Act no. 31/1990, and the operational characteristics specific to Holding companies are explained by the fact that the latter takes the position of those organizational entities specialized in taking over and managing the portfolios of other enterprises with a similar or different profile, being also separate from the type of investment or placement companies (e.g.: Mutual Investment Funds / VICs - Sicav, Securities Companies), through the very object of the competition activity. On the other hand, legislation on the functionality of joint stock companies and Limited Liability allows for the identification of optimal organizational systems for the development of Holding companies, particularly in terms of optimizing the tax (-) investment ratio. From this perspective, the analysis of the Romanian accounting system reveals the existence of the group of companies as a typical entity of the organizational configuration associated with "Holding" companies, through the "Class of Accounts 45" itself related to the "Group and Associations" records [3] [4]. In terms of competitive relations, the differences "Holding (-) Group of Companies" can be synthesized in a similar way [5] [6]:

(a) "Holding" involves the existence of some partially or fully independent organizational entities under operational control associated with the managerial specificity of a particular entity, in particular a joint stock company;

(b) the group of companies is associated according to the accounting legislation of that organizational structure based on the existence of subsidiary industrial centers, characterized by a consolidated decisional system on the analysis of capacity and financial return indicators specific to both a joint stock company and a company with limited liability; while the tax regime for investment entities specializing in participatory operations. Under Romanian accounting legislation, holdings held by a limited liability company or joint stock company are delimited in the range of $\mathbf{1 0 \%}$ $\mathbf{- 5 0 \%}$ of the total of the securities acquired by another organizational entity, while the takeover of more than $\mathbf{5 0 \%}$ of a company's portfolio changes its "identity" to a financially and operationally affiliated management center of the investing company [3] [4] [7] successive stages structured as such: 
(b.1.) dividends related to the investment company are paid by the issuing company of the respective securities (the situation of the independent, subsidiary entities) only after the payment of the tax rate for the gross profit realized, in this case $\mathbf{2 5 \%}$, to which may be added different tax rates specific to the field of activity the case of the standard tax system) [8] [2];

(b.2.) the dividends of the investing company are received in the income portfolio only after they have been subject to a taxing rate equivalent to $10 \%$ of the amount of the financial resources attributed to the associated company within the distributing company [8] [2];

(b.3.)Profits of Holding, following the acquisition of various securities portfolios, are treated as "Income from Participations", subject to the taxation regime of any organizational entity [3] [4]; aspects that delimit in fact the functional criteria that can underpin the various ways of managing corporate financial operations.

\section{ALTERNATIVES TO THE MACROECONOMIC STRATEGY FOR ATTRACTING DIRECT FOREIGN INVESTMENT. MULTINATIONAL CORPORATIONS VERSUS MACROECONOMIC POLICY IN THE EUROPEAN AND WORLD CONTEXT}

The essence of macroeconomic policies aimed at attracting foreign capital investment lies in the delimitation of those national competitive venues capable of delivering an upward trend in productivity and competitiveness of the economy as a whole but all of which are coordinated through strategic concepts that are sufficiently compatible with emerging processes in regional or even global scale. The situation of Romania viewed in this perspective is therefore quite flexible, supported by the totality of the doctrinal developments up to this moment and also by the strategic complex that has competed with the foundation of the Romanian government platforms and programs, the latter providing the conceptual and applied functionality of the components of the „matrix" of transition to the competitive economy, and at the same time the coordinates of an economic policy generating positive evolutions in the level of the development of the Romanian economy in the sense of connecting the industrial structures and the potential of the absorption markets to the requirements and exigencies of the investment media (Association Agreements with the European Union, CEFTA, NAFTA), [9] [10] [11].

In this orientation, the coordinates of Romania's economic growth policy in the context of the ascendant assimilation of the components of the regional and global integration process of the contemporary economy concern in particular the following categories:

a) strengthening the tax system, also in order to be able to ensure the reorientation of resources towards the private sector, more fluid, and at the same time to avoid the accumulation of internal public debt due to the expansion of the tax base in order to reduce its vulnerability to inflation while reducing the fiscal pressure both at the level of the national economy and at the level of the national economy on domestic companies and multinational corporations [12];

b) the permanent flexibility of the price regime and the stimulation of competition, by adjusting the rules and regulations in the field, to the standards of the European legislative system, in order to ensure a fluid character of the entire process of liberalization of the markets;

c) the promotion of monetary and foreign exchange policies, especially aimed at maintaining a relatively stable trend of purchasing power of the national currency at home 
and abroad, simultaneously with the advancement of subsidiary policies meant to ensure the firm control of the inflationary process, to coordinate the sizing budget deficit to a reasonable or equilibrium level, and last but not least, lead to consolidation of current account convertibility, favoring full exchange rate liberalization and mechanisms foreign exchange market [13];

d) directing financial and credit policy towards meeting specific objectives, strengthening financial market institutions through the continued development of the infrastructure and, at the same time, by constantly training staff to streamline financial services in Romania and align them to the required standards the process of increasing integration of the world economy;

e) the advancement of a multidirectional, even neutral industrial policy based on the allocation of resources for the development of infrastructure and the introduction of new technologies designed to help eliminate market imperfections and externalities resulting from the lack of information abundance or a coherent information system, the predominance of complicated administrative procedures, etc., along with the promotion of entrepreneurial capacity and the development of small and medium-sized enterprises, as prerequisites for asserting national competitiveness by creating value and added value in the context of some economic areas in the process of globalization;

f) regulating and continuing the environmental adaptability of the legal framework of product quality, consumer protection and brand rights in order to capitalize on Romania's competitive advantages in the already globalized world, to recognize the merits of the elite in all branches of economic life [14]; issues that do nothing but confirm, the set of strategic principles that must be taken into account when implementing any measures that may address the flexibility of national economic subsystems or the functionality of simultaneous and juxtaposed processes of transition and integration.

\section{CONCLUSION}

The emerging assemblage of the absorption markets, managed by the very nature of the competitive mechanisms, manifests in the contemporary period wide variations in terms of the incidence on the direction of the flows of foreign capital investments, in the sense that they are received and maintained in the economies of transit. The case of Romania is by far a particular one, delineated by the emergence of the consumption behavior of the population, and by the very dualistic character of the process of liberalization of the money and capital markets, aspect which has effects of dislocation of the forms under which, as a rule, operating procedures of multinational corporations.

\section{REFERENCES}

[1] Lasserre, Ph.; The Management of Large Group: Asia and Europe Compared, "European Management Journal", Vol. 10, No. 2, June 1992

[2] Dambischi, Arthur; The Holding Companies: A Romanian Environment Analysis Viewpoint, "Scientific Bulletin", Series D, Vol. 63, No. 1, 2001

[3] Bojian, Octavian; Bazele Contabilităţii, Ed. Adonai, Buc. 1995

[4] Bojian, Octavian; Contabilitatea Intreprinderilor, Ed. Eficient, Buc. 1996

[5] Bernard, Yves; Colli, Jean-Claude; Vocabulaire Economique et Financier, Editions du Seuil, Avril 1989

[6] Dobrotă, Niţă (coord.); Dicţionar de Economie, Ed. Economică, Buc. 1999 
[7] Nicolescu, Ovidiu; Management Comparat: Uniunea Europeană, Statele Unite ale Americii şi Japonia, Ed. Economică, Buc. 1997

[8] Arthur Andersen S.R.L.; Doing Business in Romania, Andersen Worldwide, October 2001(www.arthurandersen.com)

[9] Popescu, Constantin; Ciucur, Dumitru; Tranziţia prin criză, Ed. Eficient, Buc. 1995

[10] Taşnadi, Alexandru; Economia socială de piaţă, Centrul Poligrafic A.S.E., Buc. 1997

[11] Popescu, Constantin; Ciucur, Dumitru; Băbeanu, Marin; Popescu, Ion; Echilibrul inaintării, Ed. Eficient, Buc. 1998

[12] Dambischi, Arthur; Presiunea fiscală şi investiţiile corporaţiilor multinaţionale, "Finanţe, Bănci, Asigurări” Nr. 4/ Aprilie 2002

[13] Croitoru, Lucian; Macrostabilizare şi tranziţie, Ed. Expert, Buc. 1993

[14] Coşea, Mircea; Jurnal în tranziţie, Ed. Dacia, Cluj-Napoca, 2001 